\title{
Postdural puncture headache: Incidence and predisposing factors in a university hospital
}

\author{
Postdural ponksiyon baş ağrısı: Bir üniversite hastanesinde görülme insidansı ve \\ kolaylaştırıcı faktörler
}

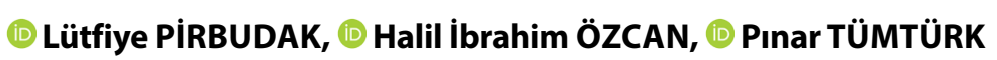

\begin{abstract}
Summary
Objectives: Postdural puncture headache (PDPH) may occur 12-72 hours after spinal anesthesia. PDPH causes patient discomfort following spinal anesthesia and therefore it presents a challenging situation for anesthetists.

Methods: This prospective randomized study enrolled 613 patients who were 18 years or older and who had been operated under spinal anesthesia. The spinal anesthesia procedure was performed with the patient in a sitting position through the L3-4, L4-5 interspaces, using 25 and 26 gauge (G) quincke and pencil-point spinal needles. The gender, age, body mass index, level of sensory block, mobilization time of the patients and also the experience and physical fatigue condition of the physicians were recorded. In the postoperative period all patients were questioned as to whether they experienced headache. These questions were repeated at postoperative $1^{\text {st }}, 24^{\text {th }}, 48^{\text {th }}$ and $72^{\text {nd }}$ hours in the hospital and on the $7^{\text {th }}$ day by phone after they were discharged.

Results: Compared to older patients, patients between the ages of 25 to $40(p<0.001)$ and compared to other operations, $C / S$ patients ( $p: 0.003$ ) experienced headaches more frequently in the postoperative period. The other two important factors were the experience ( $p: 0.013$ ) and the physical fatigue of the physician (p: 0.001) on the day of surgery.

Conclusion: The experience and good physical condition of the physician, TUR or anorectal surgery, a patient over 40 years of age and using pencil-point spinal needles during the spinal anesthesia procedure were associated with a reduced risk of postdural puncture headache.
\end{abstract}

Keywords: Pencil point spinal needle; postdural puncture headache; quincke spinal needle; spinal anesthesia.

\begin{abstract}
Özet
Amaç: Post dural ponksiyon baş ağrısı, spinal anesteziden 12-72 saat sonra ortaya çıkmaktadır. Aynı zamanda hastanın konforunu bozduğundan anestezistlerin korktuğu bir durumdur.

Gereç ve Yöntem: Bu prospektif, randomize çalışma 18 yaşüzeri, spinal anestezi altında opere olacak 613 hastada planlanmıştır. L2-L3 ve L4-L5 aralığından, 25 ve $26 \mathrm{G}$ quincke ve kalem uçlu iğneler kullanılmıştır, hastalara spinal anestezi oturur pozisyonda uygulanmıştır. Hastanın cinsiyeti, yaşı, vücut kütle indeksi, duyu bloğu düzeyi, mobilizasyon zamanı, hekimin deneyimi ve fiziksel yorgunluğu kaydedildi. Tüm hastalar 1., 24., 48. ve 72. saatlerde hastanede takip edildi ve 7. gününde baş ağrısı olup olmadıkları sorulmak üzere telefonla evlerine ulaşıldı.

Bulgular: Yaşlı hastalarla karşılaştıııldığında, 25-40 yaş arası hastalar ( $p<0.001)$ ve diğer operasyonlarla karşılaştırıldığında, sezaryen (C/S) hastaları postoperatif dönemde daha sık baş ağrısı yaşadı ( $p: 0.003$ ). Diğer iki önemli faktör, deneyim (p: 0.013) ve ameliyat günündeki doktorun fiziksel yorgunluğu ( $p$ : 0.001) idi.

Sonuç: Tecrübeli, yorgun olmayan doktorlar, TUR veya anorektal cerrahi, 40 yaş üstü hastalar ve kalem uçlu spinal iğne kullanımı postdural ponksiyon baş ağrısı sıklığını azaltacaktır.
\end{abstract}

Anahtar sözcükler: Kalem uçlu spinal iğne; postdural ponksiyon baş ağrısi; quinke Spinal iğnesi; spinal anestezi. 


\section{Introduction}

Spinal anaesthesia works by blocking the neuronal signal transduction pathway temporarily by the injection of local anaesthetics into the cerebrospinal fluid (CSF). It is one of the most commonly used regional techniques today. ${ }^{[1]}$ Postdural puncture headache (PDPH) may occur 12-72 hours following spinal anesthesia due to CSF leakage. The severity of PDPH typically increases when patients stand up from a horizontal position and it usually occurs in the bifrontal, retroorbital or occipital regions. It occurs in $3 \%$ to $10 \%$ of patients after the administration of spinal anesthesia. PDPH causes patient discomfort after spinal anaesthesia and therefore it is a challenging situation for anaesthetists. ${ }^{[2-6]}$ The aim of this study is to investigate how often PDPH occurs and what factors affect the incidence of PDPH in a university hospital.

\section{Material and Methods}

After approval from the Investigational Review Board, the study was scheduled to be performed between January 2012 and June 2012 in the Gaziantep University Medical Faculty. A randomized study was designed with 613 American Society of Anaesthesiologists (ASA) I to III, 18 years or older patients having elective cesarean section (C/S) or arthroscopy or uretherorenoscope (URS) or transurethral resection (TUR) or anorectal surgery under spinal anaesthesia. On the day before the surgery, patients were informed about the procedure, and all gave written consent. Patients were randomly assigned to 1 to 4 spinal needle groups in a predetermined ratio using a computerized randomization system. The four needles were as follows; a 25 gauge $(G)$ quincke needle (Spinocan, B. Braun Melsunger, Germany), a 26 G quincke needle (Spinocan, B. Braun Melsunger, Germany), a $25 \mathrm{G}$ pencil-point needle (Pencan, B. Braun Melsunger, Germany) and a $26 \mathrm{G}$ pencil-point needle (Pencan, B. Braun Melsunger, Germany). Patients were classified according to their ages into groups as $18-25$ and $25-40$ years and older.

Exclusion criteria were; patients with anxiety disorder, a history of allergic reactionsto any drug used in the study, coagulopathic disorders, patients who had serious cardiovascular problems, patients refusing spinal anaesthesia or those having an infection in the application area.
Demographic values, age, gender, body mass index (BMI) and ASA were recorded.

Before spinal anaesthesia, all the patients were hydrated with $10-15 \mathrm{~mL} / \mathrm{kg}$ isotonic fluid or lactate Ringer solution in a 20 min $18 \mathrm{G}$ intravenous cannula. The patients did not receive any pharmcological premedication. Routine intraoperative monitors included continuous electrocardiogram (ECG), pulse oximetry, noninvasive arterial blood pressure, and body temperature monitoring. Spinal anaesthesia was performed as determined by the attending anaesthesiologist. Spinal anaesthesia was administered under aseptic conditions. Spinal anaesthesia was administered while the patient was in a sitting position, by using the midline approach with a spinal needle that entered through the subarachnoid space via the level L2-3 or L4-5 interspace. The pencil-point needle was introduced with a $20 \mathrm{G}$ introducer, whereas the Quincke needle was introduced without it. Quincke needles were introduced with the bevel parallel to the longitudinal fibers of the dura in order not to cut the dural fibers. Free flow of the cerebrospinal fluid was observed so as to confirm the suitability of puncturing, then local anaesthetic solution was injected. Bupivacaine isobaric (Marcaine ${ }^{\mathrm{TM}} 0.5 \%$ Vial, AstraZeneca, İstanbul, Türkiye) or bupivacaine heavy (Marcaine $^{\mathrm{TM}}$ 0.5\% Ampoule; AstraZenaca, İstanbul, Türkiye) was injected with either a pencil-point or a quincke needle. The sensory block level was evaluated every 3 minutes by the loss of the pinprick sensation with a $20 \mathrm{G}$ hypodermic needle. The Bromage scale ( $0=$ free movement of legs and feet; $1=$ just able to flex knees with free movement of feet; $2=$ unable to flex knees, but with free movement of feet; $3=$ unable to move legs or feet) was used to evaluate the motor block of lower extremities. Surgical procedures were initiated after adequate sensory and motor block formation was achieved. Hypotension was defined as a $30 \%$ or more decrease in systolic blood pressure from the baseline. Hypotension was treated first with an IV volume expander and then if needed by the injection of 5-10 mg of IV ephedrine. Bradycardia was defined as a heart rate of $<45$ beats/min or a $40 \%$ or more decrease in heart rate. Bradycardia was treated with $0.01 \mathrm{mg} / \mathrm{kg}$ of IV atropine. General anaesthesia was used forpatients after inadequate spinal anaesthesia or a failed spinal block to avoid complications in the surgery. The needle type and 
number of puncture attempts were recorded. The case was excluded if more than one attempt atspinal anaesthesia was made.

The physical condition and clinical experience of the anaesthesiologist (trainee or specialist) were recorded to compare any differences in the event that the anaesthesiologist was suffering fromfatigue or had insufficient experience. In our hospital the anaesthesiologists stay for 24 hours on-call and continue to work the next day.

In the postoperative period, patients were observed in the postanaesthetic care room for 1-2 hours The patients were kept on bed rest for 6 hours. All patients were mobilized after the total return of motor function as assessed by the same anaesthesiologist. Spinal anaesthesia regression time and mobilization time were recorded. A combination of $1 \mathrm{~g}$ of IV paracetamol three times daily and $50 \mathrm{mg}$ of IV tramadol 6-hourly to a maximum of $400 \mathrm{mg}$ in a 24 hour period was given for postoperative analgesia.

The patients were given $2-3 \mathrm{~L}$ fluid per day and patients were interviewed by the anaesthesiologist about headache, back pain or any other complications (nausea, vomiting, tinnitus, ect...) on the $1^{\text {st }}$, $2^{\text {nd }}, 3^{\text {rd }}$ and $7^{\text {th }}$ postoperative day (where they had been discharged from hospital they were interviewed by telephone). Patients were questioned as to whether they had experienced headache or not; if the answer was "yes" they were asked what kind of headache the patient experienced. PDHD was diagnosed by the anaesthesiologist based on the criteria of the International Headache Society (IHS).

According to the diagnostic criteria of the IHS,PDPH is diagnosed if the headache worsens within $15 \mathrm{~min}$ utes after sitting or standing and improves within 15 minutes after lying, and at least one of the following and fullfilling criteria accompanies the headache: neck stiffness, tinnitus, hyperacusis, photophobia, nausea and if the headache develops within 5 days dural puncture. ${ }^{[7]}$

Other types of headaches were considered nonspecific headaches and were excluded from the study. The intensity of PDPH was classified as mild, moderate, and severe headache postoperatively by a visual analog scale (VAS) on the $1^{\text {st }}, 2^{\text {nd }}, 3^{\text {rd }}$ and $7^{\text {th }}$ postoperative days. On the scale, 0 is the absence of headache, 1-3 is mild pain, 4-6 is moderate pain, and 7-10 is sever pain (disabling; unable to perform daily activities). Mild PDPH was defined as nagging, annoying pain and the absence of restrictions in daily activities; bed rest and fluid intake were recommended. Moderate PDPH was defined as a headache that restricts daily activities. Bed rest, liquid, and analgesic intake 6-hourly to a maximum $2 \mathrm{~g}$ a day (acetaminophen $250 \mathrm{mg}+$ propyphenazone $150 \mathrm{mg}+$ caffeine -Minoset Plus ${ }^{\circledR} 500 \mathrm{mg}$ tablet) were recommended. Severe PDPH was defined as a headache confining the patient to bed and becoming anorexic despite adequate medical treatment. The patients who had severe PDPH were first recommended bed rest with or without intravenous hydration, laxatives or oral caffeinated drinks; then given analgesic tablets (Minoset Plus ${ }^{\circledR} 500$ mg tablet) being one tablet every 6 hours. If severe PDPH persisted for more than 3 or 4 days following these treatments, an epidural blood patch (EBP) was applied to patients using autologous blood (15-20 $\mathrm{mL}$ ) after informed consent was obtained. The EBP was conducted by experienced staff anaesthesiologists under aseptic conditions. Once the epidural was injected with an $18 \mathrm{G}$ Touchy needle via the loss of resistance technique, $15-20 \mathrm{ml}$ of blood was drawn from the patient's orearm. The blood was carefully, aseptically and slowly (over approximately 10 seconds) drawn by the anaesthesiologist through the epidural needle. Phlebotomy was first performed after first identifying the epidural space to avoid coagulation. The procedure continued while $15-20 \mathrm{ml}$ of autologous blood was injected totally or while low back pain, neck pain, radicular pain continued spreading to the legs or worsening headache occurred. ${ }^{[8]}$ After removing the cannula, patients routinely had bed rest in a supine position for 2 hours during which timeroutine vital monitoring continued. Vital monitoring continued for two hours after the procedure in a sitting position. Patients were evaluated clinically for intensity of the headache and radicular pain with VAS.

The effectiveness of EBP was evaluated by asking the patient to stand up and walk after 2 hours. PDPH was evaluated on the $1^{\text {st }}$ postoperative day and on the $7^{\text {th }}$ day by phone call. 
Table 1. Patients characteristics $(n=602)$

\begin{tabular}{|c|c|}
\hline A & \\
\hline \multicolumn{2}{|l|}{ Age (year) } \\
\hline $18-25 / 26-40 / 40<, n$ & $79 / 285 / 248$ \\
\hline $\operatorname{Sex}(M / F)$ & $289 / 313$ \\
\hline $\mathrm{BMI}\left(\mathrm{kg} / \mathrm{m}^{2}\right)$ mean $\pm \mathrm{SD}$ & $25.4 \pm 6.1$ \\
\hline ASA classification (I/II/III), n & $187 / 220 / 195$ \\
\hline \multicolumn{2}{|l|}{ Type of surgery (n) } \\
\hline $\mathrm{C} / \mathrm{S}$ & 204 \\
\hline Arthroscopy & 80 \\
\hline Uretherorenoscope (URS) & 70 \\
\hline TUR & 145 \\
\hline Anorectal & 103 \\
\hline \multicolumn{2}{|l|}{ Spinal anesthesia Intervals, n } \\
\hline $\mathrm{L} 2-3$ & 296 \\
\hline L4-5 & 306 \\
\hline Bupivacaine (mg) & $12.5(10.0-17.5)$ \\
\hline Baricity (isobaric/hyperbaric) & $354 / 248$ \\
\hline \multicolumn{2}{|l|}{ Sensory block level (n) } \\
\hline T 4> & 18 \\
\hline T 4-7 & 242 \\
\hline T 7-10 & 279 \\
\hline $\mathrm{T} 10<$ & 63 \\
\hline
\end{tabular}

Data are given as mean \pm SD or numbers of patients. M: Male; $F$ : Female; BMI: Body mass index; SD: Standard deviation; ASA: American Society of Anesthesiologists physical status; C/S: Cesarean section; TUR: Transurethral resection.

Table 2. PDPH incidence for needle type

\begin{tabular}{cccc}
\hline & $\begin{array}{c}\text { Quincke } \\
(\mathbf{n}=\mathbf{2 9 8})\end{array}$ & $\begin{array}{c}\text { Pencil point } \\
(\mathbf{n = 3 0 4 )}\end{array}$ & p \\
\hline PDPH & $27(9.1)$ & $10(3.2)$ & $<0.013$ \\
\hline
\end{tabular}

PDPH: Postdural puncture headache. Numbers in the parentheses represent percentage values. Differences between groups are statistically significant. $\mathrm{P}<0.05$.

\section{Statistical analysis}

The normality of distribution of continuous variables was tested with the Kolmogorov-Smirnov test. The Student's $t$ test was used for comparison of two independent groups of variables with a normal distribution and the Mann-Whitney $U$ test was used when the distribution was abnormal. The Chi-square test was used to assess the relationshipbetween categorical variables. Risk factors were determined using binary logistic regression analysis. Descriptive statistic parameters were presented as frequency, percentage (\%) and mean \pm standard derivation (mean \pm SD).
Table 3. PDPH incidence for needle diameter

\begin{tabular}{lcc}
\hline $\begin{array}{l}\text { Spinal needle type } \\
\text { and diameter }\end{array}$ & PDPH & p \\
\hline 25 G quincke $(n=144)$ & $14(9.7)$ & $<0.981$ \\
26 G quincke $(n=154)$ & $13(84)$ & \\
25 G pencil p. $(n=164)$ & $5(3)$ & $<1$ \\
26 G pencil p. $(n=140)$ & $5(3.5)$ & \\
\hline
\end{tabular}

PDPH: Postdural puncture headache. Numbers in the parentheses represent percentage values. Differences within groups are not statistically significant.

Statistical analysis was performed with SPSS for Windows version 22.0 and a $p$ value $<0.05$ was accepted as statistically significant.

\section{Results}

The 631 patients were recruited in the study. Nine patients in the $26 \mathrm{G}$ pencil-point group and twelve patients in the $25 \mathrm{G}$ Quinke group were excluded from the study due to there being more than one attempt at spinal anaesthesia. In addition, a further nine patients were excluded because they were not available during follow-up. The spinal anesthesia was performed on 298 patients with a Quinke type needle and on 304 patients with a pencil-point type needle. The demographic and characteristics data of the patients are shown in Table 1.

No unsuccessful spinal punctures were recorded.

PDPH was observed in 27 patients (9.1\%) in the quincke groups and in 10 patients (3.2\%) in the pencil-point groups. The patients were classified according to the needle type that was used; PDPH incidence was significantly higher in the quincke group $(p<0.013)$ (Table 2). A comparison was undertaken of the diameter of spinal needles used within the group and no significant difference in PDPH incidence was found in the $25 \mathrm{G}$ and $26 \mathrm{G}$ groups (Table 3 ).

PDPH was observed in 5 patients (2.1\%) over 40 years. PDPH incidence was significantly lower in patients over 40 years compared with patients in the $18-25$ and $26-40$ age groups $(p<0.008)$ (Table 4).

As the patients were grouped according to their gender, PDPH was observed in 24 of 313 female patients (7.7\%) and in 13 of the 298 male patients (4.5\%) and 
Table 4. PDPH incidence and age

\begin{tabular}{lcc}
\hline Age & PDPH & p \\
\hline $18-25(n=79)$ & $8(10.1)$ & \\
$26-40(n=285)$ & $24(8.4)$ & $<0.008$ \\
$40<(n=238)$ & $5(2.1)$ & \\
\hline
\end{tabular}

PDPH: Postdural puncture headache; Numbers in the parentheses represent percentage values. Differences between groups are statistically significant. $\mathrm{P}<0.05$.

Table 5. PDPH incidence and surgery type

\begin{tabular}{lcc}
\hline Type of surgery & PDPH & p \\
\hline C/S $(n=204)$ & $22(10.8)$ & $<0.003$ \\
Arthroscopy $(n=80)$ & $4(5)$ & $<0.128$ \\
Uretherorenoscope (URS) $(n=70)$ & $5(7.1)$ & $=0.378$ \\
TUR $(n=145)$ & $2(1.4)$ & $<0.001$ \\
Anorectal $(n=103)$ & $4(3.9)$ & $<0.040$
\end{tabular}

PDPH: Postdural puncture headache; C/S: Cesarean section; TUR: Transurethral resection. Differences between groups are statistically significant. Numbers in the parentheses represent percentage values. $\mathrm{P}<0.05$.

no significant difference was found in terms of PDPH incidence.

$\mathrm{PDPH}$ incidence for $\mathrm{C} / \mathrm{S}$ was significantly higher than any other surgical procedures whereas anorectal surgery and transurethral resection (TUR) had lower PDPH ratios than other surgical procedures $(p<0.001)$ (Table 5).It was observed that the incidence of PDPH reduced as the trainee's experience increased $(p<0.017)$. Also, no PDPH was reported if the spinal anaesthesia was administered by a specialist (Table 6).

The correlation between the physical condition of the physician and PDPH incidence is shown at Table 7. In the study hospital the anaesthesiologists are oncall for 24 hour. PDPH incidence was found to be significantly higher in patients whose spinal block was performed by a physician who had been on-call for the previous 24 hours and who was fatigued, compared to other patients whose block was performed by a physician in a good physical condition $(p<0.023)$. All PDPH patients were treated conservatively in the first instance (including bed rest, oral and/or intravenous hydration laxatives, analgesic and oral caffeinated drinks) during their postoperative follow-up. In 28 cases (76\%), PDPH was relieved using conserva-
Table 6. PDPH incidence and experience of physician

\begin{tabular}{lcc}
\hline Experience of physician & PDPH & p \\
\hline $1^{\text {st }}$ year trainee $(n=168)$ & $14(8.3)$ & $<1$ \\
$2^{\text {nd }}$ year trainee $(n=144)$ & $12(8.3)$ & $<0.354$ \\
$3^{\text {rd }}$ year trainee $(n=144)$ & $8(5.6)$ & $<0.133$ \\
$4^{\text {th }}$ year trainee $(n=141)$ & $3(2.1)$ & $<0.017^{*}$ \\
Specialist $(n=5)$ & 0 & \\
\hline
\end{tabular}

PDPH: Postdural puncture headache; ${ }^{*} \mathrm{p}=$ comparison of $4^{\text {th }}$ year trainee and other groups. ${ }^{*} P<0.05$. Numbers in the parentheses represent percentage values.

Table7. Comparison of PDPH incidence depending on the physician's physical condition

\begin{tabular}{lcc}
$\begin{array}{l}\text { Physical condition } \\
\text { of physician }\end{array}$ & PDPH & p \\
\hline $\begin{array}{l}\text { The day after guard duty and } \\
\text { tired ( } n=126) \text { - Group A }\end{array}$ & $20(15.9)$ & ${ }^{*}<0.023$ \\
$\begin{array}{l}\text { The day after guard duty and } \\
\text { rested ( } n=162) \text { - Group B }\end{array}$ & $12(7.4)$ & ${ }^{* *}<0.001$ \\
$\begin{array}{l}\text { On a ordinary day } \\
(n=309) \text { - Group C }\end{array}$ & $5(1.6)$ & $\dagger<0.001$
\end{tabular}

PDPH: Postdural puncture headache; ${ }^{*} \mathrm{p}=$ comparison of group $A$ and $B$; ${ }^{* *} p=$ comparison of group $B$ and $C ; t p=$ comparison of group $A$ and $C$. Numbers in the parentheses represent percentage values.

tive treatments. In 9 cases (24\%), PDPH was relieved by the first administration of EBP. In this case VAS scores at the $10^{\text {th }}$ minute and in the second hour after the EBP were 0 . The success rate of EBP administration was found to be $100 \%$.

\section{Discussion}

In this study, we aimed to investigate the predisposing factors and incidence of PDPH. Both Quincke and pencil-point spinal needles used had good handling characteristics. We found that type of spinal needle, the age of the patient, surgery type, experience of the physician, and the physical state/fatigue of the physician were strongly correlated to the incidence of PDPH.

Aftab et al., ${ }^{[2]}$ reported that the incidence of PDPH changed depending on the type of spinal needles used. In 295 patients who were between the ages of 18-40 and who planned to undergo elective C/S surgery, the PDPH ratio was $23.3 \%$ in the Quincke needle group, and $4.8 \%$ in Whitacre needle group. 2 In another study, five different spinal needles - 25 
G Quincke, 26 G Atraucan, 24 G Gertie Max, 24 G Sprotte, and $25 \mathrm{G}$ Whitacre needles - were compared for PDPH incidence, and the highest ratio was found in the Quincke needle at $8.7 \%$. In our study, the PDPH incidence was found to be $9.1 \%$ with the Quincke needle, higher than a pencil-point needle. Similarly, PDPH incidence was found to be $18.1 \%$ with a Quincke needle, higher than with a Whitacre needle. ${ }^{[3]}$ Many other studies were undertaken and similarly results were found to be higher using the Quincke needle as stated in the literature. ${ }^{[2,6,9,10]}$

Our data was consistent with studies reporting an advantage ${ }^{[11]}$ or no difference ${ }^{[12]}$ using a $26 \mathrm{G}$ Quincke needle following $\mathrm{C} / \mathrm{S}$. Akdemir et al. ${ }^{[12]}$ reported that the incidence of PDPH was $4.33 \%$ versus $2.04 \%$ in the $26 \mathrm{G}$ Atraucan needles group and the $26 \mathrm{G}$ Quincke spinal needles group in elective cesarean operations.

Between two different diameter indexes of the same type of spinal needles $-25 \mathrm{G}$ and $26 \mathrm{G}$, no significant differences were found in the incidence of PDPH. As shown by other studies of $25 \mathrm{G}$ and $26 \mathrm{G}$ spinal needles, PDPH rates were found to be similar to each other. $^{[3-6]}$

A direct relationship was found between age and incidence of PDPH, in that patients under the age of 40 , experienced a significantly higher rate of PDPH Ghaleb et al., had found that the incidence of PDPH was higher in the patients aged between 18 and30 years. ${ }^{[13]}$ Pjevic et al. ${ }^{[14]}$ enrolled 776 patients between the ages of 20 and 45 and a $25 \mathrm{G}$ spinal needle was used. It was found that PDPH occurred more frequently at younger ages. Chan et al. ${ }^{[15]}$ found the incidence of PDPH to be $13.9 \%$ using a 25 G Quincke needle study that enrolled 101 patients with a mean age of 33.6 years; they emphasized in this study that PDPH is seen more frequently in younger patients. Contrarily, Schmittner et al. ${ }^{[9]}$ reported that PDPH was seen in a patient group with a mean age of 42.3; whereas PDPH was not seen in another group of patients with a mean age of 46.8 . They determined that no significant differences were found in terms of PDPH incidence in different age groups. Further, in another study in which 361 patient had elective $\mathrm{C} / \mathrm{S}$ surgery, the correlation between age and PDPH was researched and no significant differences were found. ${ }^{[6]}$
Our study showed that PDPH incidence was statistically similar for males and females. Sergio et al. ${ }^{[16]}$ investigated the PDPH incidence after lumbar puncture for 675 patients and they did not find any significant statistical differences between the male and female patient groups. Jean et al., ${ }^{[17]}$ and Hafer et al. ${ }^{[18]}$ declared that the incidence of PDPH showed no significant differences between genders. However, Despond et al. ${ }^{[19]}$ applied spinal anaesthesia to patients between the ages of 18-45 years and they found an incidence of PDPH of $20 \%$ in the female group, and $5.5 \%$ in the male group indicating that the results found a significantly higher incidence in females.

As compared to surgery type for PDPH, it was significantly higher for $\mathrm{C} / \mathrm{S}$, and lower for TUR and anorectal surgeries. It is believed that the incidence of PDPH was lower in the TUR and anorectal surgery as these types of surgery were generally performed on elderly patients. Srivastava et al. ${ }^{[20]}$ investigated the incidence of PDPH in 200 patients by grouping them as obstetric and non-obstetric patients. They found that the ratio for obstetric patients was higher. This could be explained by the fact that intra-abdominal pressure in pregnant women was higher due to the narrowing of the epidural space, and thus could result in more CSF leakage. ${ }^{[18]}$

The effect of the physical fatigue of the physicianand their clinical experience on the incidence of PDPH was also observed. There were no PDPH cases following spinal anaesthesia procedure undertaken by specialists. However, the reason for this may have been the limited of patients. When trainees were compared according to their years of experience significant differences were found. As experience increased, PDPH was seen less frequently. Also, when a physician felt fatigue after a difficult period of on-call duty, more PDPH cases were seen. This result was associated with loss of attention by the physician. Tien et al., ${ }^{[21]}$ reported that the incidence of PDPH varied depending on the extent of teaching and supervision of trainess in lumbar epidural procedures. In this study, lumbar epidural procedures performed by less experienced anaesthesiologists and those performed outside office hours were associated with a higher incidence of accidental dural puncture. When the incidence of an event was analyzed according to the anaesthesiologists' grade, junior trainees and 
non-trainees with at least two years' experiance had similar event rates: $0.021 \%$. Advanced trainees had a lower rate of $0.016 \%$ while consultant anaesthetists had the lowest event rate of $0.013 \%$. Akdemir et al. ${ }^{[12]}$ reported that the incidence of PDPB was $2.04 \%$ in the $26 \mathrm{G}$ Quincke spinal needles group in elective cesarean operations. The incidence of PDPH reported by Akdemir et al. ${ }^{[12]}$ is lower than the incidence of PDPH in this study found in elective cesarean operations.

Finally, PDPH remission was successful in $76 \%$ of the patients based on medical treatment with bed rest, hydration, and analgesics. In the remaining the patients with PDPH - 24\%- an epidural blood patch was performed and all complaints were resolved following application. Marcus et al. ${ }^{[22]}$ reported that medical therapy had a $94.5 \%$ success rate and application of an epidural blood patch had a $90-99 \%$ success rate. ${ }^{[23]}$ In another study, bed rest, hydration and analgesics were used during medical therapy in patients who developed PDPH, and remission of PDPH was achieved in $50 \%$ of the cases in the first 4 days. ${ }^{[24]}$

\section{Conclusion}

The experience and good physical condition of the physician and the use of pencil-point spinal needles during spinal anesthesia procedures were found to be associated with a reduced risk of postdural puncture headache. In addition, the incidence of PDPH was found to be low in patients over 40 years of age, who underwent anorectal and TUR surgery. PDPH may disrupt the relationship between mother and infant in the postnatal period. Therefore, it is recommended that experienced anaesthesiologists in good physical condition should perform anaesthesia in obstetric patients.

\section{Conflict-of-interest issues regarding the authorship or article: None declared.}

\section{Peer-rewiew: Externally peer-reviewed.}

\section{References}

1. Morgan GE Jr, Mikhail MS, Murray MJ. Obstetric anesthesiology. In: Morgan GE Jr, Mikhail MS, Murray MJ, editors. Clinical Anesthesiology. 4th ed. New York: McGraw-Hill Companies; 2006. p. 890-921.

2. Aftab S, Nur-Ul-Haq S, Jehan H. Postdural Puncture Headeche: Comparison of 26 G Quincke with 25G Whitacre Needle For Ceserian Section. Pakistan Journal of Surgery 2009;25:257-61.
3. Vallejo MC, Mandell GL, Sabo DP, Ramanathan S. Postdural puncture headache: a randomized comparison of five spinal needles in obstetric patients. Anesth Analg 2000;91(4):916-20.

4. Buettner J, Wresch KP, Klose R. Postdural puncture headache: comparison of 25-gauge Whitacre and Quincke needles. Reg Anesth 1993;18(3):166-9.

5. Tabedar S, Maharjan SK, Shrestha BR, Shrestha BM. A comparison of 25 gauge Quincke spinal needle with 26 gauge Eldor spinal needle for the elective Caesarian sections: insertion characteristics and complications. Kathmandu Univ Med J (KUMJ) 2003;1 (4):263-6.

6. Etezadi F, Yousefshahi F, Khajavi M. et. al. Post Dural Puncture Headache after Cesarean Section, a Teaching Hospital Experience. Journal of Family and Reproductive Health 2012;6(1):17-21.

7. Turnbull DK, Shepherd DB. Post-dural puncture headache: pathogenesis, prevention and treatment. $\mathrm{Br} J$ Anaesth 2003;91(5):718-29.

8. Pirbudak L, Uğur MG, Kaya Uğur B, Kul S, Ganidağlı S. Evaluation of affecting factors and the effectiveness of treatment in cases with post-dural puncture headache who underwent epidural blood patch. Agri 2014;26(3):101-6.

9. Schmittner MD, Terboven $T$, Dluzak $M$, Janke $A$, Limmer $M E$, Weiss $C$, et al. High incidence of post-dural puncture headache in patients with spinal saddle block induced with Quincke needles for anorectal surgery: a randomised clinical trial. Int J Colorectal Dis 2010;25(6):775-81.

10. Schmittner MD, Urban N, Janke A, Weiss C, Bussen DG, Burmeister MA, et al. Influence of the pre-operative time in upright sitting position and the needle type on the incidence of post-dural puncture headache (PDPH) in patients receiving a spinal saddle block for anorectal surgery. Int J Colorectal Dis 2011;26(1):97-102.

11. Abdullayev R, Küçükebe OB, Çelik B, Kirman N, Hatipoğlu HS, Akaltun Hatipoğlu F. Does Atraucan cause more postdural puncture backache? Turk J Med Sci 2015;45(4):877-81.

12. Akdemir MS, Kaydu A, Yanlı Y, Özdemir M, Gökçek E, Karaman $\mathrm{H}$. The Postdural Puncture Headache and Back Pain: The Comparison of 26-gauge Atraucan and 26-gauge Quincke Spinal Needles in Obstetric Patients. Anesth Essays Res 2017;11(2):458-62.

13. Ghaleb A, Khorasani A, Mangar D. Post-dural puncture headache. Int J Gen Med 2012;5:45-51.

14. Pjević M, Gvozdenović L. Postspinal headache-incidence and prognosis [Article in Croatian]. Med Pregl 1993;46(56):201-4.

15. Chan L, Delilkan AE. Incidence of postdural puncture headache. A prospective study of 101 spinal anaesthetics in orthopaedic patients. Med J Malaysia 1992;47(1):20-6.

16. de Almeida SM, Shumaker SD, LeBlanc SK, Delaney $P$, Marquie-Beck J, Ueland $S$, et al. Incidence of post-dural puncture headache in research volunteers. Headache 2011;51(10):1503-10.

17. Jeanjean P, Montpellier D, Carnec J, Crasquin O, Koral E, Line $B$, et al. Headaches after spinal anesthesia: prospective multicenter study of a young adult population. [Article 
in French]. Ann Fr Anesth Reanim 1997;16(4):350-3.

18. Hafer J, Rupp D, Wollbrück M, Engel J, Hempelmann G. The effect of needle type and immobilization on postspinal headache. [Article in German]. Anaesthesist 1997;46(10):860-6.

19. Despond O, Meuret P, Hemmings G. Postdural puncture headache after spinal anaesthesia in young orthopaedic outpatients using 27-g needles. Can J Anaesth 1998;45(11):1106-9.

20. Srivastava V, Jindal P, Sharma JP. Study of post dural puncture headache with 27G Quincke \& Whitacre needles in obstetrics/non obstetrics patients. Middle East J Anaesthesiol 2010;20(5):709-17.
21. Tien JC, Lim MJ, Leong WL, Lew E. Nine-year audit of postdural puncture headache in a tertiary obstetric hospital in Singapore. Int J Obstet Anesth 2016;28:34-38.

22. Marcus HE, Fabian A, Dagtekin O, Schier R, Krep H, Böttiger BW, et al. Pain, postdural puncture headache, nausea, and pruritus after cesarean delivery: a survey of prophylaxis and treatment. Minerva Anestesiol 2011;77(11):1043-9.

23. Feuer MP. Spinal Anestezi: Dura Ponksiyonu Sonrası Baş Ağrısı. In: Atlee LJ, editor. Çiçek M, çev. Ed. Anestezide komplikasyonlar. Adana: Nobel Kitabevi; 2012. P. 223-6.

24. Bezov D, Ashina S, Lipton R. Post-dural puncture headache: Part II-prevention, management, and prognosis. Headache 2010;50(9):1482-98. 